\title{
FIG URES
}

[I] Oscar H. Will and Company catalog, I9II I4

[2] Oscar Will in a field of Dakota White Flint corn, I9II 24

[3] Oscar H. Will and Company catalog, 192226

[4] Scattered Corn Woman of Elbowoods, North Dakota, 191628

[5] Woman using bone hoe in Maxi' diwiac's garden, 191230

[6] Origin of the maize landrace Zapalote Grande, I95I 40

[7] Herbarium specimen of Tripsacum collected by Paul Mangelsdorf, n.d. 49

[8] Hugh and Marian Cutler packing ears of maize, Cochabamba, Bolivia, circa 194I SI

[9] A dugout canoe used by Hugh and Marian Cutler on the Paraguay River, I94I 52

[Io] Edgar Anderson measuring a sample of maize, circa 1948 6I

[iI] Researcher in the corn seed bank of the Office of Special Studies, Mexico, 195468

[12] Researchers examine races of maize from Central America, I959 79

[13] Air-conditioning to improve seed storage, 1960s $8 I$

[14] Corn of the Caribbean arranged for study, 1960s 86

[I5] A seed scientist in the US National Seed Storage Laboratory, 195993

[16] The movement of seeds within the US National Plant Germplasm System, 1981 96

[17] Map of the centers of origin of agricultural crops, circa I920S IOI

[18] Map showing the spread of CIMMYT wheat varieties, $1967 \quad 107$ 
[19] Twenty-Third Conference of the Food and Agriculture Organization, $1983 \quad$ I24

[20] Czesława Prywer Lidzbarska and students at the Postgraduate College, Mexico, 1960 s 128

[2I] Efraím Hernández Xolocotzi and his students examine maize varieties, $198 \mathrm{I} \quad \mathrm{I32}$

[22] Erna Bennett with a group of farmers near Karpenisi, Greece, 1969142

[23] Booklet describing important elements of the Mexican Food System, I980s 149

[24] Field Day of the Germplasm Enhancement of Maize project, 2008 I62

[25] The organizational structure of the National Plant Germplasm System, 1981 I7I

[26] Printed catalogs of seed bank collections, I980s 177

[27] Flowchart representing the mechanics of seed requests from CIMMYT, $1986 \quad I 84$

[28] Southwest Traditional Crop Conservancy Garden and Seed Bank's annual seed list, 1982 Igo

[29] Flowchart by the Soil and Health Society illustrating the movement of seeds, 1981 196

[30] Diverse sites of seed conservation depicted in The Community Seed Bank Kit, $198620 I$

[31] Researcher associated with Project MILPA interviews a Mexican farmer, $1990 \mathrm{O} 210$

[32] Intercropped plot of maize and beans included in Project MILPA activities, I990s 215

[33] Protest materials produced by Network in Defense of Maize, 2015 219 